\title{
A study of autotrophic communities in two Victoria Land lakes (Continental Antarctica) using photosynthetic pigments
}

\author{
Francesca BORGHINI*, Andrea COLACEVICH and Roberto BARGAGLI \\ Department of Environmental Sciences, University of Siena, Via P.A. Mattioli 4, 53100 Siena, Italy \\ *e-mail corresponding author: borghini@unisi.it
}

\begin{abstract}
The composition of algal pigments and extracellular polymeric substances (EPS) was determined in microbial mats from two lakes in Victoria Land (Continental Antarctica) with different lithology and environmental features. The aim was to expand knowledge of benthic autotrophic communities in Antarctic lacustrine ecosystems, providing reference data for future assessment of possible changes in environmental conditions and freshwater communities. The results of chemical analyses were supported by microscopy observations. Pigment profiles showed that filamentous cyanobacteria are dominant in both lakes. Samples from the water body at Edmonson Point had greater biodiversity, fewer pigments and lower EPS ratios than those from the lake at Kar Plateau. Differences in mat composition and in pigment and EPS profile between the two lakes are discussed in terms of local environmental conditions such as lithology, ice-cover and UV radiation. The present study suggests that a chemical approach could be useful in the study of benthic communities in Antarctic lakes and their variations in space and time.
\end{abstract}

Key words: Antarctic lakes, microbial mats, algal pigments, EPS

\section{INTRODUCTION}

Many lakes and ponds in Antarctic ice-free areas provide an environment for phototrophic organisms that is more buffered than soils against desiccation, solar radiation and low temperatures (Bargagli 2005). A large proportion of organic matter in continental Antarctica is found as benthic mats of cyanobacteria, chlorophytes and phytoflagellates in freshwater ecosystems (Vincent 2000). These phototrophs support simple truncated food webs, which in Victoria Land (East Antarctica) include a wide range of heterotrophic bacteria, fungi, protozoans, and few species of rotifers, nematodes and tardigrades.

The biomass and morphology of freshwater microbial mats is affected by many factors such as the duration, thickness and transparency of the ice-cover, sediment features, water depth and chemistry (e.g., Hodgson et al. 2004; Sabbe et al. 2004). These mats generally show a vertical stratification of different cyanobacteria and contain high concentrations of extracellular polymeric substances (EPS), varying quantities of mineral sediments and large voids occupied by water (de lo Rios et al. 2004). EPS are probably involved in biofilm formation and adherence processes, and they are thought to play an important role in the survival and growth of cyanobacteria under extreme conditions because they provide protection against desiccation and predation (De Philippis \& Vincenzini 1998). Typical pond mats have a heavily pigmented superficial layer of cyanobacteria: their black, brown or orange pigments very effectively screen out harmful UV radiation (Ehling-Schulz 1997;
Squier et al. 2004). The underlying green layer has the highest photosynthetic rate in the mat and is supersaturated with oxygen. A few millimetres below, oxygen is depleted because it is consumed by bacterial decomposition.

Many Antarctic lakes lack an outlet; they therefore reflect biogeochemical processes occurring both in the lake and in the surrounding catchment and are among the most reliable early warning indicators of local climatic and environmental changes (e.g., Borghini \& Bargagli 2004; Hodgson et al. 2006; Hodgson \& Smol 2008). Simple phototrophic communities in Antarctic lakes are adapted to cope with extreme environmental conditions and are more exposed to ecological changes than freshwater communities at lower latitudes, where responses to external forcing and potential colonists are buffered by more complex biological interactions and feedback processes (Bargagli 2005). At Signy Island, for instance, climate warming is increasing primary production (Quayle et al. 2002). Although Victoria Land is one of the most important limnological regions in Continental Antarctica, only a few lakes such as those in the McMurdo Dry Valleys have been thoroughly investigated (e.g., Wharton et al.1993; Priscu 1998; Vopel \& Hawes 2006; Vincent \& Laybourn-Parry 2008). Very few data are available on lacustrine mats in northern Victoria Land, and all are from microscopy studies. This study is part of a multidisciplinary project aimed at creating a database of the biological and ecological characteristics of lakes and ponds. Previous studies (Borghini \& Bargagli 2004; Borghini et al. 2007; 2008) have shown that those in the region have very different biogeochemical characteristics. 
Despite the low taxonomic resolution, HPLC analysis of sedimentary pigments could be a rapid tool for compiling a database of the main algal groups present. This is because some photosynthetic pigments in planktonic and benthic phototrophs, for example chlorophyll- $a$ (chl- $a$ ) and $\beta$-carotene ( $\beta$-car), are ubiquitous among the different taxa, whereas others (e.g., lutein, fucoxanthin and zeaxanthin) are markers of specific algal groups (Chlorophyta, diatoms and cyanobacteria, respectively; e.g., Jeffrey et al. 1997).

Preliminary surveys on water chemistry and sedimentary pigments (Borghini et al. 2007) found that two lakes in areas with different lithology, latitude and environmental characteristics (Edmonson Point and Kar Plateau) have very different prototroph communities, but similar water chemistry. This study aimed to better characterize these communities through the analysis of EPS and algal pigments and through microscopic observation of microbial mats. In particular, it aimed to: a) assess whether biotic variations are linked to different environmental conditions and; b) compare microscopic and chemical data for the study of microbial mats in Victoria Land lakes. The chemical approach, simpler and less time-consuming than microscopic analysis, may be useful in extensive studies of mats and their temporal and spatial variations in composition and responses to changing environmental conditions. Sediment samples were also analyzed using a technique that is more sensitive and selective than that used in the previous work.

\section{METHODS}

\subsection{Study area}

Kar Plateau is a coastal ice-free area (roughly $4 \mathrm{~km}^{2}$ wide, at an altitude of about $160 \mathrm{~m}$ ) located in the northern Granite Harbour region (Fig. 1). Granitic bedrocks form an upland which is confined to the North by a glacier and to the South and the East by a granite cliff capped by dolerite (Taylor 1914). Kar Plateau has a very rich moss and lichen flora compared to other icefree areas in the region (Seppelt et al. 1995), and some of the ponds and small lakes have no ice-cover in summer. Although there are some studies on soils (Ugolini 1977), mosses and lichens (Schofield \& Ahmadjian 1972, Seppelt et al. 1995; Cannone 2006) from this area, to our knowledge there are no data for algae from lakes and ponds. Borghini et al. (2007) analyzed water samples from the biggest lake at Kar Plateau and found that their chemistry is affected by marine aerosol and elements leached from rocks and soils; according to the classification based on total $\mathrm{N}$ and P concentrations (Volleiweider \& Kerekes 1982), it is a meso-euthrophic lake.

Edmonson Point is one of the largest (about $6 \mathrm{~km}^{2}$ ) of the few low-lying ice-free coastal areas in northern Victoria Land (Fig. 1). The area comprises relatively gently sloping gravel and cobble beaches and numerous knolls (200-300 m high) and moraines separated by small valleys. The volcanic substrate is generally dark and solar radiation leads to rapid snowmelt in summer, with the formation of ephemeral streams and ponds. In small valleys and depressions the availability of water and nutrients (mainly from nesting Adelie penguins and south polar skuas) favours the development of moss and algae communities and a wide range of freshwater habitats (from oligotrophic to eutrophic conditions). Broady (1985) studied the morphological taxonomy of microalgal and cyanobacterial communities at Edmonson Point and reported 42 taxa in algal mats, soils, bryophytes and rocks. More recently, Cavacini \& Fumanti (2005) reported 102 taxa from the same area applying morphological taxonomy: mostly Cyanobacteria with subordinate Bacillariophyta and minor Xanthophyta. These authors found that this community composition is rather common in freshwater habitats along the Victoria Land coast (from Cape Hallett to Wright Valley); however, autotrophic communities at Edmonson Point have the highest diversity. Lake 14, located in a small depression about $300 \mathrm{~m}$ from the coastline, is eutrophic and its sediments are covered by extensive microbial mats (Borghini et al. 2007).

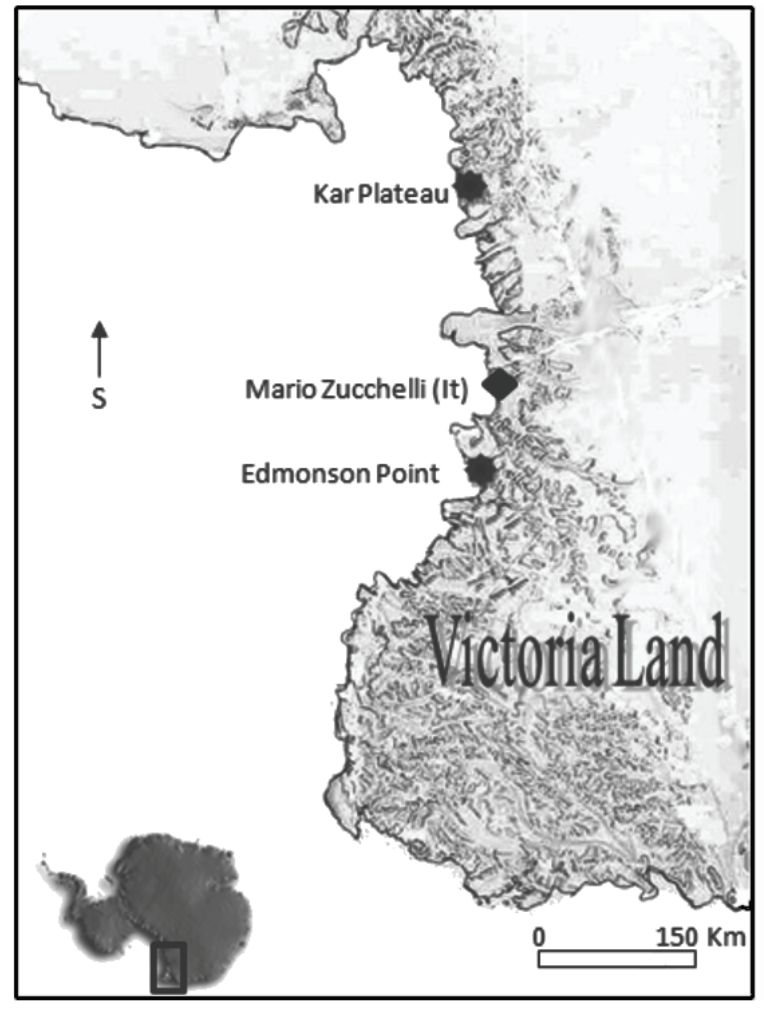

Fig. 1. Sampling stations in Victoria Land.

\subsection{Sampling}

Three mat samples were collected from the largest lake at Kar Plateau and from Lake 14 at Edmonson Point during the last week of January 2005; the main 
characteristics of the two water bodies are summarized in table 1. Microbial mats were hand-sampled about 0.5 $\mathrm{m}$ from the littoral zone using a metal corer and gloves. Sediment samples were collected by a metal hand-corer about at the same distance of the mats in the littoral zone free from microbial mats. Samples wrapped in silver paper were brought back to the Italian "M. Zucchelli" Antarctic Station and stored at $-20^{\circ} \mathrm{C}$ for transport to Italy. The samples were preserved frozen and in the dark until analysis.

Tab. 1. Main environmental characteristics and water chemistry (mean ion concentrations in $\mu \mathrm{g} \mathrm{mL}^{-1}$ and conductivity in $\mu \mathrm{S} \mathrm{cm}{ }^{-1}$ ) and sediment ( $\mathrm{S}$ and $\mathrm{P}$ in $\mu \mathrm{g} \mathrm{g}^{-1} \mathrm{dw}$; TOC, TC and $\mathrm{TN}$ in \%; from Borghini et al. 2007) of the two lakes.

\begin{tabular}{|c|c|c|}
\hline & Kar Plateau & Edmonson Point \\
\hline Latitude S & $76.91065^{\circ}$ & $74.32942^{\circ}$ \\
\hline Longitude E & $162.54123^{\circ}$ & $165.13292^{\circ}$ \\
\hline Altitude (m) & 160 & 20 \\
\hline Catchment lithology & granitic & volcanic \\
\hline Distance from the sea $(\mathrm{m})$ & 500 & 500 \\
\hline Estimated surface $\left(\mathrm{m}^{2}\right)$ & 2900 & 4000 \\
\hline Presence of birds & few & few \\
\hline Ice-cover (at the time of sampling) & partial & no ice \\
\hline Mats and sediments sampling depth $(\mathrm{cm})$ & 30 & 30 \\
\hline Lake depth (m) & 4 & 1 \\
\hline $\mathrm{TN}$ & 3.50 & 2.10 \\
\hline $\mathrm{TP}$ & 0.10 & 0.15 \\
\hline $\mathrm{Na}^{+}$ & 50.84 & 63.09 \\
\hline $\mathrm{K}^{+}$ & 3.60 & 6.28 \\
\hline $\mathrm{Mg}^{2+}$ & 15.77 & 5.07 \\
\hline $\mathrm{Ca}^{2+}$ & 23.08 & 6.96 \\
\hline $\mathrm{Cl}^{-}$ & 162.22 & 115.21 \\
\hline $\mathrm{SO}_{4}{ }^{2-}$ & 2.27 & 5.89 \\
\hline $\mathrm{pH}$ & 9.1 & 9.3 \\
\hline Conductivity & 993 & 1180 \\
\hline S & 365 & 539 \\
\hline $\mathrm{P}$ & 515 & 587 \\
\hline $\mathrm{TC}$ & 0.50 & 1.53 \\
\hline $\mathrm{TN}$ & 0.13 & 0.20 \\
\hline TOC & 0.30 & 0.69 \\
\hline
\end{tabular}

\subsection{EPS analysis}

Total EPS were extracted with 2\% EDTA in lyophilized fractions of known weight. The extracted carbohydrates were determined using the phenol-sulphuric method (Herbert et al. 1971) with glucose as the standard. The protein content in the EPS was determined according to Bradford (1976) using bovine serum albumin as the standard.

\subsection{Photosynthetic pigment and Total Organic Carbon (TOC) analysis}

About $2 \mathrm{~g}$ of freeze-dried bulk sediment and $0.2 \mathrm{~g}$ of lyophilized mat were extracted with $5 \mathrm{~mL}$ of acetone by sonication and stored for 1 hour at $5{ }^{\circ} \mathrm{C}$ in the dark. The procedure was repeated three times. Extracts were centrifuged at $3500 \mathrm{rpm}$ for $10 \mathrm{~min}$ and filtered before atmospheric pressure chemical ionization- liquid chromatography-mass spectrometry and photodiode array (APCI LC-MS-PDA) analysis. Ammonium acetate 0.1
M ( $10 \%$ of the sample) was added to the sample just before HPLC injection. $50 \mu \mathrm{L}$ of sample were injected into reversed-phase columns (Spherisorb ODS2 Hypersil, $150 \times 4.6 \mathrm{~mm}$ ID, $5 \mu \mathrm{m}$ particle size equipped with ODS2 pre-column) were used along with a solvent system and gradients slightly modified from Pinckney et al. (1996). LC-MS was performed using a Thermo system comprising a Finnigan surveyor autosampler, a MS pump and a Finnigan LTQ. APCI LC-MS was performed in the positive ion mode, and MS instrument settings were as follows: capillary temperature of 250 ${ }^{\circ} \mathrm{C}$, APCI vaporizer temperature of $350{ }^{\circ} \mathrm{C}$, discharge current of $5.5 \mu \mathrm{A}$, discharge voltage of $4 \mathrm{kV}$, sheath gas flow rate of 40 a.u. (arbitrary units), auxiliary gas flow rate of 14 a.u., sweep gas flow rate of 0 a.u.

Peaks were identified by their absorption spectra at their maximum wavelength and characteristic $\mathrm{MS}^{2}$ fragmentation. Pigment quantification was performed by comparing the HPLC peak areas with those of standards (chlorophyll- $a$, chlorophyll- $b$ ) from Sigma-Aldrich Chemie Gmbh and alloxanthin, antheraxanthin, 19'-butanoyloxyfucoxanthin, cantaxanthin, $\alpha-$ and $\beta, \beta$-carotene, chlorophyllide- $a$, chlorophyll- $c 2$, chlorophyll- $c 3$, divinyl chlorophyll- $a$, fucoxanthin, diadinoxanthin, echinenone, 19'-hexanoyloxyfucoxanthin, lycopene, myxoxanthophyll, neoxanthin, peridinin, pheophytin- $a$, pheophorbide- $a$, lutein, prasinoxanthin, violaxanthin, zeaxanthin) from the International Agency for ${ }^{14} \mathrm{C}$ Determination VKI in Hoersholm, Denmark and using published extinction coefficients (Hurley \& Watras 1991; Villanueva et al. 1994; Jeffrey et al. 1997) when standards were unavailable. The specific extinction coefficient used for scytonemins was $112.6 \mathrm{~L} \mathrm{~g}^{-1}$ $\mathrm{cm}^{-1}$ (Vincent et al. 2004). When extinction coefficients were unavailable or when no structurally or spectrally similar pigment existed, the value of 2500 for $\beta, \beta$-carotene was used (Jeffrey et al. 1997). Results are expressed in $\mathrm{ng} \mathrm{g}^{-1}$ dry wt for mat and $\mathrm{ng} \mathrm{g}^{-1}$ TOC for sediment samples. Mat and sediment samples were analyzed in duplicate with a precision of $<10 \%$. The taxonomic inferences made from the HPLC analyses were verified through the observation of mat samples under a light microscope.

TOC concentrations were determined using an elemental analyzer (2400 Series II, Perkin-Elmer) prior to acid treatment, applied in order to remove carbonates. All samples were analyzed in triplicate. Blanks were run during each analytical session to verify the absence of contamination, and a certificate reference soil sample (GBW-07411) was used to check the accuracy of CHNS analysis.

\section{RESULTS}

Under the microscope the microbial mats from the lake at Kar Plateau appeared green, with a quite homogeneous unlayered structure; they consisted almost exclusively of the nostocal Anabaena sp., with minor 
Tab. 2. Average compound concentrations (expressed in $\mu \mathrm{g} \mathrm{g}^{-1} \mathrm{dw}$ and $\mathrm{mg} \mathrm{TOC}^{-1}$ in mat and sediment samples, respectively) from Edmonson Point (EP) and Kar Plateau (KP) lakes. t: trace quantities. Main $\mathrm{UV}-\mathrm{Vis}$ absorbtion bands $(\mathrm{nm})$ and $\mathrm{MS}$ data $(\mathrm{m} / \mathrm{z})$ are reported.

\begin{tabular}{|c|c|c|c|c|c|c|}
\hline & \multirow{2}{*}{$\begin{array}{c}\text { UV/Vis } \\
(\mathrm{nm})\end{array}$} & \multirow{2}{*}{$\begin{array}{c}{[\mathrm{M}+\mathrm{H}]} \\
(\mathrm{m} / \mathrm{z})\end{array}$} & \multicolumn{2}{|c|}{ Microbial mats } & \multicolumn{2}{|c|}{ Sediments } \\
\hline & & & EP & KP & EP & $\mathrm{KP}$ \\
\hline Unidentified UV photoprotective compound & 338 & & 1.64 & & & \\
\hline Unidentified carotenoid & 454 & & & & & 0.29 \\
\hline Scytonemin derivative & $356,456,580$ & & & & 2.34 & 4.05 \\
\hline Reduced scytonemin & $356,442,580$ & 547 & 26.70 & 418 & 27.85 & 16.63 \\
\hline Scytonemin derivative & $384,460,570$ & & 1.43 & & & 39.38 \\
\hline Unidentified UV photoprotective compound & 340 & & & & & 2.56 \\
\hline Scytonemin & 388 & 545 & 1.15 & 500 & 7.46 & 2.09 \\
\hline Scytonemin & 388 & 545 & 2.90 & 222 & 8.25 & 3.02 \\
\hline Fucoxanthin & 452 & 641 & $\mathrm{t}$ & & $\mathrm{t}$ & \\
\hline Unidentified UV photoprotective compound & 328 & & 2.50 & & & 5.93 \\
\hline Unidentified carotenoid & $466,496,528$ & & & & 0.21 & \\
\hline Unidentified carotenoid & $466,496,528$ & & 0.40 & & 0.39 & \\
\hline Unidentified carotenoid & $468,496,530$ & & 1.46 & & 0.37 & \\
\hline Unidentified carotenoid & $440,474,504$ & & 62.60 & & 1.68 & \\
\hline Unidentified carotenoid & 482,504 & & & & 0.82 & \\
\hline Neoxanthin & $414,436,464$ & 583 & & & 1.71 & \\
\hline Unidentified carotenoid & $450,474,504$ & & 36.20 & & 2.35 & \\
\hline Unidentified carotenoid & $420,450,476$ & & 1.24 & & 0.66 & \\
\hline Unidentified carotenoid & $448,474,504$ & & 9.38 & 2.69 & 1.28 & \\
\hline Unidentified carotenoid & $444,474,504$ & & & & 0.55 & \\
\hline Myxoxanthophyll & $450,474,504$ & 760 & 2.10 & 0.96 & 3.27 & \\
\hline Unidentified carotenoid & $444,474,504$ & & 1.71 & & 0.25 & \\
\hline Unidentified carotenoid & 440,474 & & 2.18 & & 0.19 & \\
\hline Lutein & $418,446,474$ & 551 & & $\mathrm{t}$ & & \\
\hline Zeaxanthin & $422,452,476$ & 569 & 1.80 & 0.29 & 3.24 & \\
\hline Unidentified carotenoid & $444,468,498$ & & 1.37 & & 0.68 & \\
\hline Unidentified carotenoid & 474 & & 0.54 & & $\mathrm{t}$ & \\
\hline Unidentified carotenoid & $445,474,504$ & & & & 0.13 & \\
\hline Unidentified carotenoid & $440,468,498$ & & & & 0.15 & \\
\hline Unidentified carotenoid & 474 & & & & 0.68 & \\
\hline Unidentified carotenoid & $444,468,498$ & & & & 0.15 & \\
\hline Unidentified carotenoid & $444,468,498$ & & & & 0.06 & \\
\hline trans-Canthaxanthin & 474 & 565 & 8.54 & 3.02 & 0.22 & \\
\hline cis-Canthaxanthin & 370,466 & 565 & 0.96 & & & \\
\hline Bacteriochlorophyll- $a$ & $366,606,770$ & & 6.36 & & 4.47 & \\
\hline Chlorophyll- $b$ & 468,650 & 907 & & $\mathrm{t}$ & 0.73 & \\
\hline Chlorophyll- $a$ & 430,664 & 893 & 73.20 & 63.30 & 19.13 & 1.19 \\
\hline Chlorophyll a epimer & 430,664 & 893 & $\mathrm{t}$ & 3.27 & 0.41 & \\
\hline Echinenone & 466 & 551 & 9.91 & 2.98 & 0.59 & \\
\hline Bacteriopheophytin- $a(\mathrm{p})$ & $358,526,750$ & 889 & & $\mathrm{t}$ & & \\
\hline Pyropheophytin- $b$ & 654 & 827 & & & $\mathrm{t}$ & \\
\hline Pheophytin- $a$ & 408,664 & 871 & 35.0 & 10.1 & 5.66 & 1.78 \\
\hline trans- $\beta, \beta$-Carotene & $422,452,476$ & 537 & & & 0.12 & \\
\hline Pheophytin a epimer & 408,666 & 871 & & & 0.38 & \\
\hline Pyropheophytin- $a$ & 408,666 & 813 & & & 1.02 & 0.48 \\
\hline
\end{tabular}

Chroococcus sp. and rare Chlorophyta organisms. Mats from Lake 14 had orange surfaces and green undersides and, like those from other East Antarctic lakes (Taton et al. 2006), mainly consisted of filamentous cyanobacteria (Oscillatoriales), Chroococcales and diatoms.

Pigment concentrations in superficial sediments and mats from the two lakes (Tab. 2) revealed that although scytonemins (both native and derivatives) were dominant in samples from Kar Plateau, they were present in much lower concentrations in samples from Edmonson Point. Mats from the two lakes contained myxoxanthophyll, zeaxanthin and echinenone (markers of cyanobacteria) and comparable chl- $a$ concentrations. Samples from Edmonson Point had a higher number of unidentified carotenoids, with a UV-Vis spectrum resembling that of myxoxanthophyll. Only samples from Lake 14 contained traces of fucoxanthin, whereas those from Kar Plateau contained lutein and traces of chl- $b$, which indicate the presence of diatoms and Chlorophyta, respectively.

The ratio between scytonemins and cyanobacterial carotenoids (Scyt:TCC) and that between scytonemins and total chl- $a$ (Scyt: Tchl $a$ ) were about 30 times higher in the Kar Plateau Lake than in Lake 14 (Scyt:TCC 44.4 and 1.5 respectively; Scyt: Tchla 10.8 and 0.44 respectively), whereas the TCC:Tchla ratio was comparable in the two lakes (0.32 and 0.25 at Lake 14 and Kar Plateau, respectively).

Carbohydrate concentrations in Kar Plateau mats (Tab. 3) were 3-5 times higher than those in mats from 


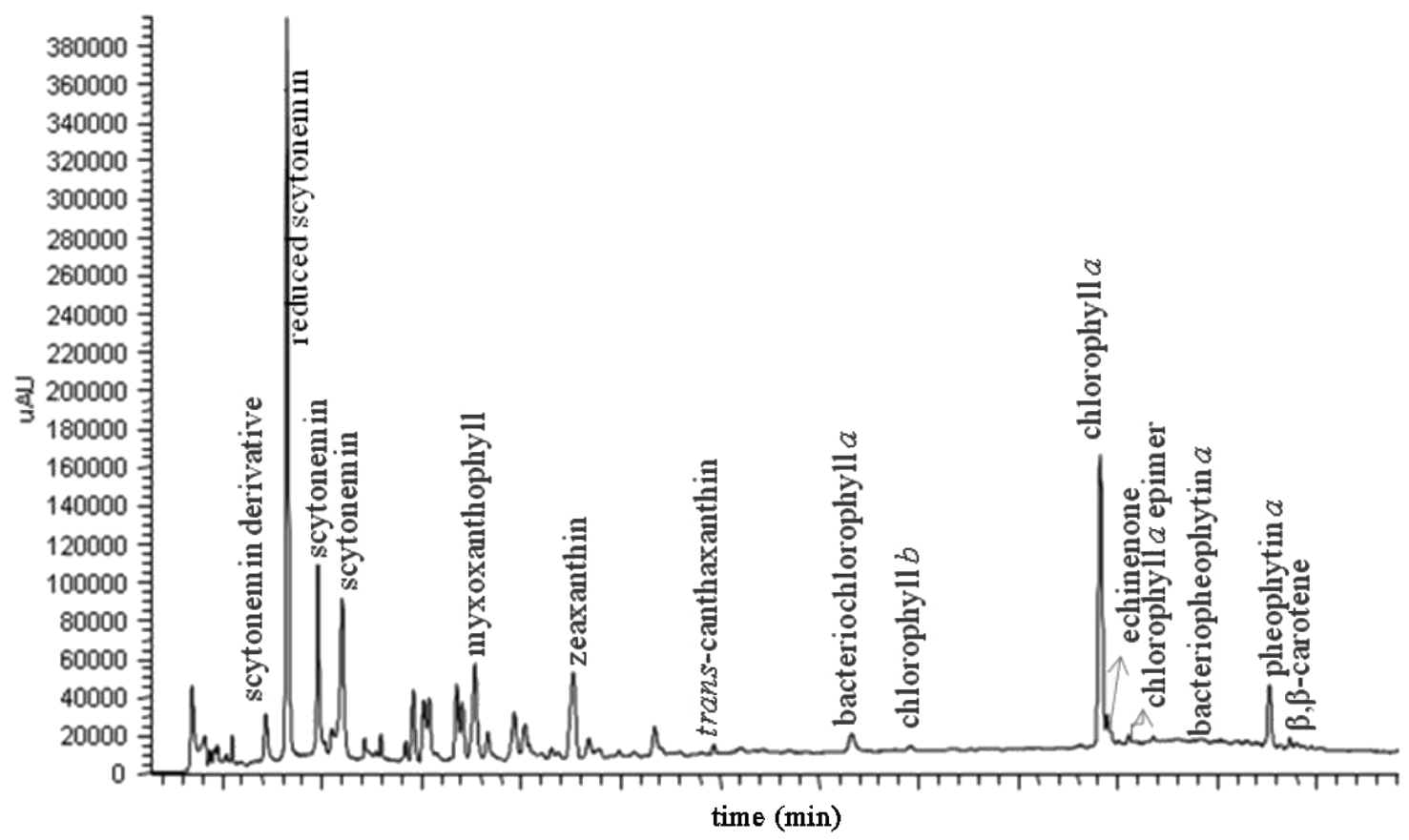

Fig. 2. HPLC-PDA (200-800 nm) chromatogram of Edmonson Point sediment sample.

Lake 14, whereas total protein concentrations in samples from the two lakes were comparable (Tab. 3).

Chl- $a$, chl- $b$ and related pheophytins, lutein, fucoxanthin, scytonemins, a series of unidentified carotenoids and bacteriochlorophyll- $a$ were detected in sediment samples (Tab. 2, Fig. 2). Sediments showed lower pigment diversity than mats and had high pheophytin contents.

Tab. 3. Average carbohydrate and protein concentrations (expressed in $\mathrm{mg} \mathrm{g}^{-1} \mathrm{dw} \pm \mathrm{SD}$ ) and their ratio.

\begin{tabular}{lccc}
\hline Site & Carbohydrates & Proteins & Carbohydrate/Protein \\
\hline Lake 14 & & & \\
sample 1 & $25.47 \pm 4.33$ & $2.74 \pm 0.07$ & 9.29 \\
sample 2 & $11.74 \pm 1.43$ & $2.34 \pm 0.28$ & 5.02 \\
sample 3 & $22.07 \pm 4.76$ & $1.90 \pm 0.13$ & 11.61 \\
Kar Plateau & & & \\
sample 1 & $63.36 \pm 2.51$ & $3.70 \pm 0.65$ & 17.12 \\
sample 2 & $118.60 \pm 3.28$ & $3.39 \pm 0.73$ & 34.98 \\
sample 3 & $156.83 \pm 12.81$ & $1.76 \pm 0.24$ & 89.11 \\
\hline
\end{tabular}

\section{DISCUSSION}

The higher pigment diversity at Edmonson Point agrees with the microscopy data: only 3 taxa in Kar Plateau mats and 7 taxa (1 Oscillatoriales, 1 Nostocales, 2 filamentous cyanobacteria, 1 Chroococcales, 1 Nitzschia sp., 1 pennate diatom) in Lake 14 mats.

The chlorophyll and carotenoid concentrations in table 2 are in the same range as those reported for mat collected at Lake Fryxell (McMurdo Dry Valleys; Buffan-Dubau et al. 2001). When compared with the pigment pattern reported by Vincent \& Quesada (1994) and Buffan-Dubau et al. (2001) for Nostoc commune and oscillatoriacean mats from lakes and streams in the Dry Valleys, the composition of mats from Lake 14 (low levels or no scytonemins and high concentrations of myxoxanthophyll, echinenone and canthaxanthin) resembled that of oscillatoriacean mats. In contrast, scytonemin was the major peak in the Kar Plateau sample, like in the N. commune mats. Scytonemin is produced by some cyanobacteria as extracellular sheaths; like myxoxanthophyll and canthaxanthin (Vincent \& Quesada 1994), it is UV-inducible and protects organisms against the deleterious effects of UV radiation (Garcia-Pichel \& Castenholz 1991).

Biological receipt of UVR was estimated from the sum of scytonemin and related pigments, expressed as a ratio, and total cyanobacterial carotenoids (TScyt:TCC). Estimates of cyanobacterial receipt of PAR+UVR were derived using an index based on the ratio of cyanobacterial carotenoids to total chlorophyll- $a$ (TCC:TChla). To investigate the proportion of metabolic effort cells expended on photo-protection versus photosynthetic production, scytonemins were expressed as a ratio with total chlorophyll-a (TScyt:TChla, Hodgson et al. 2005). The ratios between photoprotective pigments and carotenoids to chl- $a$ concentrations suggest a stronger UV stress in the Kar Plateau Lake in spite of its more persistent ice-cover. However, as mat samples were collected from the littoral zone of the two lakes, we cannot exclude that the ice-cover does not vary greatly between the two lakes. The carbohydrate/total protein ratio for the Kar Plateau Lake is higher than that for Lake 14, suggesting that conditions are more stressful at the former site. The carbohydrate/total protein ratio may provide information on trophic status: when $\mathrm{N}$ and $\mathrm{P}$ are 
lacking, proteic synthesis is reduced, a high carbohydrate/total protein ratio therefore suggests that nutrients are unbalanced. Diatoms, for instance, may increase EPS production when nutrients are lacking (Alcoverro et al. 2000). Otero \& Vincenzini (2004) proposed a model for the synthesis of EPS in cyanobacteria; their results demonstrated that, in Nostoc, EPS serve as a sink for fixed carbon when $\mathrm{C} / \mathrm{N}$ metabolism is unbalanced. Increases in UV radiation can also determine higher EPS production in cyanobacteria (e.g., Ehling-Schulz et al. 1997).

Sediments are the main sinks of solute and particulate matter in the catchment, comprising both phytoplankton and phytobenthos communities: the higher pigment diversity and chl- $a$ concentrations measured in the Edmonson Point sediment samples may therefore indicate a richer planktonic population in Lake 14, whereas the high pheophytin content in the sediments indicates a high degree of pigment degradation. As in a previous study (Borghini et al. 2007), the pigment diversity of Kar Plateau sediments was lower than that of sediments from eutrophic sites in the same region.

Pheophytin a was the main breakdown product of chl- $a$. Although the distributions of chl- $a$ and its degradation products are closely related, several processes such as senescence, photodegradation, bacterial degradation and herbivore grazing, as well as environmental factors, affect their relative concentrations. Many attempts have been made to identify specific sources of particular chl a products. Chlorine steryl esters (CSEs) are usually regarded as specific markers of grazing activity (Squier et al. 2005). No CSEs were found in the superficial sediment of the studied lakes, suggesting scarce grazing.

Although Anabaena sp. has been detected quite regularly in Antarctic lakes (e.g., Vincent et al. 1993; Jungblut et al. 2005; Singh et al. 2008), most benthic autotrophic communities are dominated by oscillatorian cyanobacteria (e.g., Nadeau \& Castenholz 2000; Taton et al. 2003; Sabbe et al. 2004). The different species composition in the two studied lakes with comparable trophic status and water chemistry (Borghini et al. 2007) may be ascribed to different local environmental conditions such as ice-cover characteristics, UV radiation receipt and catchment lithology. The first affects mat structure and composition both directly by physical disturbance and indirectly by influencing light availability (Sabbe et al. 2004; Quesada et al. 2008). The ice-cover was more persistent at Kar Plateau, whereas Lake 14 waters were characterized by strong water evaporation in summer and consequent salinization, with rapid changes in environmental conditions. Lacustrine conductivity was always higher at Lake 14 than at the Kar Plateau Lake. Oscillatorian species, common in hypersaline lakes (Oren 2000; Jungblut et al. 2005), are more sensitive to visible and UV irradiance (Nadeau et al. 1999). The Nodularia genus is frequently found in mat communities of the McMurdo Ice Shelf (Taton et al. 2003), possibly because their ability to fix nitrogen is advantageous in these highly oxic environments; for example, Nostoc sp. is found in the lacustrine mats of the Dry Valleys and McMurdo Ice Shelf (e.g., HowardWilliams et al. 1989; Vincent et al. 1993; Hawes \& Schwarz 1999; Jungblut et al. 2005). Nostocales generally have UV-screening compounds which enable them to survive in high UV environments (Leavitt et al. 2001). These factors could explain the dominance of Anabaena sp. in the Kar Plateau mat.

Lithological differences may also affect biotic composition: biological stratification in mat communities has been found to be associated with mineralogical stratification (de los Rios et al. 2004). The stochastic nature of colonisation (Davey \& Clarke 1991) and historical factors (Vyverman et al. 2007) must also be considered. Similarly, morphological-taxonomical analyses of benthonic communities in the lakes and ponds of the Larsemann Hills and Bølingen Is. (East Antarctica) revealed the presence of 26 diatom morphospecies and 33 cyanobacterial morphotypes. Different cyanobacterial assemblages were present in deep lakes and shallow ponds (Sabbe et al. 2004; Taton et al. 2006).

\section{CONCLUSIONS}

The benthic communities of two meso-eutrophic lakes in Victoria Land have very different structure and composition. Filamentous cyanobacteria are dominant in both lakes: Nostocales with a homogeneous profile are found in the Kar Plateau Lake, whereas laminated Oscillatoriales dominate Lake 14. The pigment-inferred biodiversity in the former mat is low when compared with not only lower latitude environments in Maritime Antarctica (in line with the general trend of decreasing diversity with increasing latitude) but also environments in the same region (Lake 14 at Edmonson Point) and of continental Antarctica in general; the pigment profile agrees with microscopy results. The ratio of photoprotective pigments to chl- $a$ and that of carbohydrates to total proteins were higher in the Kar Plateau Lake than in Lake 14, suggesting that UV stress was greater in the Kar Plateau Lake. This consideration and the higher evaporation rate at Lake 14 may explain the Oscillatoriales dominance at Edmonson Point.These differences in mat composition and pigment profiles could be due to local environmental conditions such as lithology, icecover and UV radiation. This study demonstrates how a chemical approach can be a valuable tool for studying the composition of the lacustrine biota and environmental conditions, and may provide an useful baseline for assessing possible future changes in Antarctic freshwater ecosystems extending the set of lakes.

\section{REFERENCES}

Alcoverro, T., E. Conte \& L. Mazzella. 2000. Production of mucilage by the Adriatic epipelic diatom Cylindrotheca 
closterium (Bacillariophyceae) under nutrient limitation. $J$. Phycol., 36: 1087-1095.

Bargagli, R. 2005. Antarctic Ecosystems. Environmental Contamination, Climate Change, and Human Impact. Ecological Studies 175, Springer, Berlin, New York, USA: $392 \mathrm{pp}$.

Borghini, F. \& R. Bargagli. 2004. Changes of major ion concentrations in melting snow and terrestrial waters from northern Victoria Land, Antarctica. Antarct. Sci., 16: 107-115.

Borghini F., A. Colacevich \& R. Bargagli. 2007. Water geochemistry and sedimentary pigments in northern Victoria Land lakes, Antarctica. Polar Biol., 30(9): 1173-1182.

Borghini, F., A. Colacevich., T. Caruso \& R. Bargagli. 2008: Temporal variation in the water chemistry of northern Victoria Land lakes (Antarctica). Aquatic Sci., 70: 134-141.

Bradford, M.M. 1976. A rapid and sensitive method for the quantification of microgram quantities of protein utilizing the principle of protein dye binding. Anal. Biochem., 72: 248-259.

Broady, P.A. 1985. A preliminary report of phycological studies in Northern Victoria Land on Ross Island during 1984-85. Melbourne University, Programme in Antarctic Studies, Rep. 66: 132.

Buffan-Dubau, E., O. Pringault \& R. de Wit. 2001. Artificial cold-adapted microbial mats cultured from Antarctic lake samples. 1. Formation and structure. Aquat. Microb. Ecol., 26: $115-125$.

Cannone, N. 2006. A network for monitoring terrestrial ecosystems along a latitudinal gradient in Continental Antarctica. Antarct. Sci., 18(4): 549-560.

Cavacini, P. \& B. Fumanti. 2005. Cyanobacterial and algal biodiversity at Edmonson Point (northern Victoria Land, Antarctica). In: Luporini, P. \& M. Morbidoni (Eds), Proceedings of the Fifth PNRA Meeting on Antarctic Biology. Polarnet Tech Rep 1/2005: 19-22.

Davey, M.C. \& K.J. Clarke. 1991. The spatial distribution of microalgae on Antarctic fellfield soils. Antarct. Sci., 3: 257-263.

de los Rios, A., C. Ascaso, J. Wierzchos, E. Fernandez-Valiente \& A. Quesada. 2004. Microstructural characterization of cyanobacterial mats from the McMurdo Ice Shelf, Antarctica. Appl. Environ. Microbiol., 70(1): 569-580.

De Philippis, R. \& M. Vincenzini. 1998. Exocellular polysaccharides from cyanobacteria and their possible applications. FEMS Microbiol. Rev., 22: 151-175.

Ehling-Schulz, M., W. Bilger \& S. Scherer. 1997. UV-B-induced synthesis of photoprotective pigments and extracellular polysaccharides in theterrestrial Cyanobacterium Nostoc commune. J. Bacteriol., 179: 1940-1945.

Garcia-Pichel, F. \& R.W. Castenholz. 1991. Characterization and biological implications of scytonemin, a cyanobacterial sheath pigment. J. Phycol., 27: 395-409.

Hawes, I. \& A.M. Schwarz. 1999. Photosynthesis in an extreme shade environment: benthic microbial mats from lake Hoare, a permanently ice-covered Antarctic lake. $J$. Phycol., 35: 448-459.

Herbert, D., P.J. Phipps \& R.E. Strange. 1971. Chemical analysis of microbial cells. In: Norris J.R. \& D.W. Ribbons (Eds), Methods in Microbiology, Vol. 5B, Academic Press, London: 209-344.

Hodgson, D.A. \& J.P. Smol. 2008. High latitude paleolimnology. In: Vincent W.F. \& J. Laybourn-Parry, Polar Lakes and Rivers. Limnology of Artic and Antarctic Aquatic Ecosystems. Oxford University Press, Oxford, UK: 43-64.

Hodgson, D.A., W. Vyverman, E. Verleyen, P.E. Leavitt, K. Sabbe, A.H. Squier \& B.J. Keely. 2005. Late Pleistocene record of elevated UV radiation in an Antarctic lake. Earth Planet. Scie Lett., 236: 765-772.

Hodgson, D.A., D. Roberts, A. McMinn, E. Verleyen, B. Terry, C. Corbett \& W. Vyverman. 2006. Recent rapid sa- linity rise in three East Antarctic lakes. J. Paleolimnol., 36(4): 385-406.

Hodgson, D.A., W. Vyverman, E. Verleyen, K. Sabbe, P.R. Leavitt, A. Taton, A.H. Squier \& B.J. Keely. 2004. Environmental factors influencing the pigment composition of in situ benthic microbial communities in east Antarctic lakes. Aquat. Microb. Ecol., 37: 247-263.

Howard-Williams, C., R. Pridmore, M.T. Downes \& W.F. Vincent. 1989. Microbial biomass, photosynthesis and chlorophyll- $a$ related pigments in the ponds of the McMurdo Ice Shelf, Antarctica. Antarct. Sci., 1(2): 125-131.

Hurley, J.P. \& C.J. Watras. 1991. Identification of bacteriochlorophylls in lakes via reverse-phase HPLC. Limnol. Oceanogr., 36(2): 307-315.

Jeffrey, S.W., R.F.C. Mantoura \& T. Bjornland. 1997. Phytoplankton Pigments in Oceanography: Guidelines to Modern Methods. UNESCO Publishing, Paris: $661 \mathrm{pp}$.

Jungblut, A.D., I. Hawes, D. Mountfort, B. Hitzfeld, D.R. Dietrich, B.P. Burns \& B.A. Neilan. 2005. Diversity within cyanobacterial mat communities in variable salinity meltwater ponds of McMurdo Ice Shelf, Antarctica. Environ. Microbiol., 7: 519-529.

Leavitt, P.R. \& D.A. Hodgson. 2001. Sedimentary pigments. In: Smol, J.P., H.J.B. Birks \& W.M.Last (Eds), Tracking Environmental Changes Using Lake Sediment: Terrestrial Algal and Siliceous Indicators. Developments in Paleoenvironmental Research. Kluwer, Dordrecht: 295-325.

Nadeau, T.L. \& R.W. Castenholz. 2000. Characterization of psychrophylics oscillatorians (cyanobacteria) from Antarctic meltwater ponds. J. Phycol., 36: 914-923.

Nadeau, T.L., C. Howard-Williams \& R.W. Castenholz. 1999. Effects of solar UV and visible irradiance on photosynthesis and vertical migration of Oscillatoria sp. (Cyanobacteria) in an Antarctic microbial mat. Aquat. Microb. Ecol., 20: $231-243$

Oren, A. 2000. Mycosporine-like amino acids as osmotic solutes in a community of halophilic cyanobacteria. Geomicrobial J., 14: 231-240.

Otero, A. \& M. Vincenzini. 2004. Nostoc (Cyanophyceae) goes nude: extracellular polysaccharides serve as a sink for reducing power under unbalanced $\mathrm{C} / \mathrm{N}$ metabolism. $J$. Phycol., 40: 74-81.

Pinckney, J.L., D.F. Millie, K.E. Howe, H.W. Paerl \& J.P. Hurley 1996. Flow scintillation of ${ }^{14} \mathrm{C}$-labeled microalgal photosynthetic pigments. J. Plankton Res., 18(10): 18671810.

Priscu, J.C. 1998. Ecosystem Dynamics in a Polar Desert: the McMurdo Dry Valleys, Antarctica. Am. Geophys Union, Washington DC, Antarct. Res. Ser. 72.

Quayle, W.C., L.S. Peck, H. Peat, J.C. Ellis-Evans \& P.R. Harrigan. 2002. Extreme responses to climate change in Antarctic lakes. Science, 295: 645.

Quesada, A., E. Fernandez-Valiente, I. Hawes \& C. HowardWilliams. 2008. Benthic primary production in polar lakes and rivers. In: Vincent W.F. \& J. Laybourn-Parry (Eds), Polar Lakes and Rivers. Limnology of Arctic and Antarctic Aquatic Ecosystems. Oxford University Press: 179-196.

Sabbe, K., D.A. Hodgson, E. Verleyen, A. Taton, A. Wilmotte, K.A. Vanhoutte \& W. Vyverman. 2004. Salinity, depth and the structure and composition of microbial mats in continental Antarctic lakes. Freshwat. Biol., 49: 236319.

Schofield, E. \& V. Ahmadjian. 1972. Field observations and laboratory studies of some Antarctic cold desert cryptogams. In: Llano G.A. (Ed), Antarctic Terrestrial Biology. Am. Geophys. Union, Washington DC, Antarct. Res. Ser. 20: 97-142.

Seppelt, R.D., T.G.A. Green \& B. Schroeter. 1995. Lichens and mosses from the Kar Plateau, Southern Victoria Land, Antarctica. N. Z. J. Bot., 33: 203-220. 
Singh, M.S., P. Singh \& N. Thajuddin. 2008. Biodiversity and distribution of Cyanobacteria at Dronning Maud Land, East Antarctica. Acta Bot. Malacitana, 33: 17-28.

Squier, A.H., R.L. Airs, D.A. Hodgson \& B.J. Keely. 2004. Atmospheric pressure chemical ionization liquid chromatography mass spectrometry of the ultraviolet screening pigment scytonemin; characteristic fragmentations. Rapid Comm. Mass Spec., 18: 2943-2938.

Taton, A., S. Grubisic, E. Brambilla, R. De Wit \& A. Wilmotte. 2003. Cyanobacterial diversity in natural and artificial microbial mats of Lake Fryxell (McMurdo Dry Valleys, Antarctica): a morphological and molecular approach. Appl. Environ. Microbiol., 69(9): 5157-5169.

Taton, A., S. Grubisic, P. Balthasart, D.A. Hodgson, J. Laybourn-Parry \& A. Wilmotte. 2006. Biogeographical distribution and ecological ranges of benthic cyanobacteria in East Antarctic lakes. FEMS Microbiol. Ecol., 57: 272-289.

Taylor, G. 1914. Physiography and Glacial Geology of East Antarctica (Continued). Geogr. J., 44(6): 553-565.

Ugolini, F.C. 1977. The protoranker soils and the evolution of an ecosystem at Kar Plateau, Antarctica. In: Llano, G.A. (Ed.), Adaptions within Antarctic Ecosystems. Smithsonian Institution, Washington, USA: 1091-1110.

Villanueva, J., J.O. Grimalt, R. de Wit, B. Keely \& J.R. Maxwell. 1994. Chlorophyll and carotenoid pigments in solar saltern microbial mats. Geochim. Cosmochim. Acta, 58(21): 4703-4711.

Vincent, W.F. \& A. Quesada 1994. Ultraviolet radiation effects on cyanobacteria: implications for Antarctic microbial ecosystems. In: Weiler, C.S. \& P.A. Penhale (Eds), Ultraviolet Radiation in Antarctica: Measurements and Biological Effects. Antarct. Res. Ser. 62: 111-124.

Vincent, W.F., M.T. Downes, R.W. Castenholz \& C. HowardWilliams. 1993. Community structure and pigment organization of cyanobacteria-dominated microbial mats in Antarctica. Eur. J. Phycol., 28: 213-221.
Vincent, W.F. 2000. Evolutionary origins of Antarctic microbiota: invasion, selection and endemism. Antarct. Sci., 12: 374-385.

Vincent, W.F., M.T. Downes, R.W. Castenholz \& C. HowardWilliams. 1993. Community structure and pigment organization of cyanobacteria-dominated microbial mats in Antarctica. Eur. J. Phycol., 28: 213-221.

Vincent, W.F., D.R. Mueller \& S. Bonilla. 2004. Ecosystems on ice: the microbial ecology of Markham Ice Shelf in the high Arctic. Cryobiology, 48: 103-112.

Vincent, W.F. \& A. Quesada. 1994. Ultraviolet radiation effects on cyanobacteria: implications for Antarctic microbial ecosystems. In: Weiler, C.S. \& P.A. Penhale (Eds), Ultraviolet Radiation in Antarctica: Measurements and Biological Effects. Am. Geophys. Union, Washington DC, Antarct. Res. Ser. 62: 111-124.

Vincent, W.F. \& Laybourn-Parry. 2008. Polar Lakes and Rivers. Limnology of Arctic and Antarctic Aquatic Ecosystems. Oxford University Press, New York: 327 pp.

Vyverman, W., E. Verleyen, K. Sabbe, K. Vanhoutte, M. Sterke, D.A. Hodgson, D.G, Mann, S. Juggins, B. Van de Vijver, V. Jones, R. Flower, D. Roberts, V.A. Chepurnov, C. Kilroy, P. Vanormelingen \& A. De Wever. 2007. Historical processes constrain patterns in global diatom diversity. Ecology, 88: 1924-1931.

Volleiweider, R.A. \& J. Kerekes. 1982. Eutrophication of Waters. Monitoring, Assessment and Control. Organization for Economic Co-operation and Development (OECD), Paris: $154 \mathrm{pp}$.

Vopel, K. \& I. Hawes. 2006. Photosynthetic performance of benthic microbial mats in Lake Hoare, Antarctica. Limnol. Oceanogr., 5: 1801-1812.

Wharton, R.A., B.C. Parker \& G.M. Simmons. 1983. Distribution, species composition and morphology of algal mats in Antarctic Dry Valley lakes. Phycologia, 22: 355-265.

Received: March 2010

Accepted: June 2010 